\title{
The effects of BRL-50481 on ovalbumin-induced asthmatic lung inflammation exacerbated by co-exposure to Asian sand dust in the murine model
}

\author{
Hong Jo Kim ${ }^{1}$ Jin Yong Song ${ }^{1}$ Tae II Park ${ }^{1}$. \\ Won Seok Choi ${ }^{1} \cdot$ Jong Heon Kim $^{1} \cdot$ Oh Seong Kwon ${ }^{1}$. \\ Ji-Yun Lee ${ }^{1,2}$ (1)
}

Received: 19 July 2021 / Accepted: 25 December 2021 / Published online: 4 January 2022

(C) The Pharmaceutical Society of Korea 2022

\begin{abstract}
Asian sand dust (ASD), which mainly originates in China and Mongolia in the spring and blows into Korea, can exacerbate respiratory and immunological diseases. This study aims to observe effects of co-exposure to ASD on ovalbumin (OVA)-induced asthmatic lung inflammation and of treatment with a phosphodiesterase 7 (PDE7) inhibitor in a mouse model. The challenge with OVA increased airway hyperresponsiveness (AHR) and inflammatory cell infiltration into the lung tissue. Interleukin (IL)-13, tumor necrosis factor-alpha, monocyte-protein-1, mucin, and antigen-specific $\mathrm{IgE}$ and $\mathrm{IgG1}$ production increased in mouse serum. The co-exposure of ASD significantly exacerbated these effects in this asthma model. Notably, the administration of a PDE7 inhibitor, BRL-50481 (BRL), significantly reduced AHR, infiltration of inflammatory cells into the lungs, and the levels of type $2 \mathrm{~T}$ helper cell-related cytokines, antigenspecific immunoglobulins, and mucin. Thus, the administration of BRL ameliorated OVA-induced allergic asthmatic responses exacerbated by co-exposure to ASD. This study suggests that PDE7 inhibition can be a therapeutic strategy for inflammatory lung diseases and asthma via the regulation
\end{abstract}

Hong Jo Kim and Jin Yong Song have contributed equally to this work.

Supplementary Information The online version contains supplementary material available at https://doi.org/10.1007/ s12272-021-01367-x.

Ji-Yun Lee

jylee98@cau.ac.kr

1 College of Pharmacy, Chung-Ang University, Seoul 06974, Republic of Korea

2 Pathophysiology, College of Pharmacy, Chung-Ang University, Seoul 06974, Republic of Korea of T lymphocytes and reduction of IL-13, and, consequently, mucin production.

Keywords Asthma · Asian sand dust · PDE7 inhibitor . IL-13 · Mucin

\section{Introduction}

Asthma is a common, noncommunicable, chronic disease that affects $\sim 334$ million people worldwide (Bonser and Erle 2017). It is mainly characterized by airway inflammation, immunoglobulin $\mathrm{E}$ (IgE) generation, and production of type 2 helper T cell (Th2) cytokines (Sethi et al. 2019; Yeon et al. 2019). Various inflammatory cells, including lymphocytes, mast cells, eosinophils, and sputum granulocytes, are recruited and aggravate asthma by releasing granule proteins or inflammatory mediators (Kim et al. 2016; Chen et al. 2020a). The combination of airway smooth-muscle constriction and inflammation of the bronchi causes airway obstruction in asthma and the consequent symptoms of cough, shortness of breath, chest tightness, and wheezing (Fanta 2009).

Asian sand dust (ASD) is a sandstorm that originates from the northwest desert of Mongolia and China and blows into Korea, Taiwan, and Japan by way of the westerlies, especially in the spring season (Shin et al. 2019). The exposure of airway epithelial cells to ASD can reduce cellular viability and promote proinflammatory responses. Furthermore, it can exacerbate respiratory and immunological diseases (Honda et al. 2014). A previous study showed that ASD enhanced allergic inflammatory responses in an allergic asthma model (Lee et al. 2018). A panel study reported a negative association of exposure to ASD with pulmonary function (Watanabe et al. 2016). Another study in a murine model found that ASD enhances the 
infiltration of eosinophils in the airway, suggesting that ASD in the atmosphere may contribute to the aggravation of asthma (Ichinose et al. 2006).

Cyclic adenosine monophosphate (cAMP) plays an important role in the pathogenesis of asthma. cAMP signaling leads to airway smooth muscle relaxation and bronchodilation (Ha et al. 2017). It inhibits a number of immune and inflammatory responses, including T-cell activation and proliferation, tumor necrosis factor (TNF)- $\alpha$ production in monocytes and macrophages, superoxide anion production in eosinophils, and eosinophil chemotaxis via inflammatory mediators (Jin et al. 2010). Intracellular cAMP is degraded and inactivated by numerous phosphodiesterases (PDEs), a superfamily of isoenzymes that consists of 11 families (Torphy 1998). There are many trials being conducted on the use of PDE inhibitors for the treatment of asthma because of their bronchodilatory and antiinflammatory activities (Matera et al. 2014). For example, roflumilast is a PDE4 inhibitor reported to ameliorate airway inflammation, inhibit allergeninduced airway hyperresponsiveness (AHR), and bronchoconstriction induced by allergens and exercise (Al-Sajee et al. 2019). Recently, several studies have been conducted targeting PDE to alleviate COVID-19 (Yim et al. 2021).

PDE7 exists in two isoforms, 7A and 7B, both known to be cAMP-specific enzymes. Furthermore, PDE7 has been found in a broad range of cells and tissues, including the spleen, brain, lung, kidney, and lymphoid and myeloid cells, particularly T lymphocytes (Page 2014). PDE7A is involved in normal T-cell activation, and PDE7 inhibitors influence lymphocyte function and certain types of inflammatory responses (Maurice et al. 2014).

PDE7 inhibitors, such as BRL-50481 (BRL), have pharmacological effects on proinflammatory responses in human blood monocytes, lung macrophages, and $\mathrm{CD} 8^{+} \mathrm{T}$-lymphocytes believed to contribute to inflammation (Smith et al. 2004). Neuroprotective effects of BRL on sevofluraneinduced neurodegeneration have also been reported recently (Chen et al. 2020b).

Previous studies suggest that ASD may exacerbate the inflammation of allergic asthma. However, the relationship between asthma and PDE7 is poorly understood. In this study, the relationship between ASD-exacerbated asthma and PDE7 was investigated by administering BRL to an ovalbumin (OVA)-induced asthmatic lung inflammation mouse model co-exposed to ASD.

\section{Materials and methods}

\section{Materials}

Ovalbumin (grade V from chicken egg white, lyophilized powder, $\geq 98 \%$ ), BRL-50481 ( $\geq 98 \%$ ), dexamethasone (DEX, $\geq 98 \%$ ), and xylazine were purchased from Sigma-Aldrich (St Louis, MO, USA). Aluminum hydroxide (Imject ${ }^{\circledR}$ Alum) gel was purchased from Thermo Fisher Scientific (Rockford, IL, USA), Zoletil@50 from Virbac Korea (Seoul, Republic of Korea), and acetyl- $\beta$-methylcholine chloride (Methacholine chloride) from Santa Cruz Biotechnology (Dallas, TX, USA).

\section{Animals}

A total of 70 specific pathogen-free BALB/c mice (5 weeks old) were purchased from Youngbio (Kyunggido, Republic of Korea). They were housed under standard laboratory conditions for 7 days for acclimation. The environment was maintained at $24 \pm 2{ }^{\circ} \mathrm{C}$ at $50 \pm 5 \%$ humidity with a $12: 12 \mathrm{~h}$ light/dark cycle. Pathogen-free food and water and sterilized bedding were provided. The mice were randomly divided into seven groups ( $\mathrm{n}=10$ per each group): (1) a vehicle control group; (2) a BRL group; (3) an OVA group; (4) an ASD group; (5) an OVA+ASD group; (6) an OVA+ASD+BRL group; and (7) an OVA+ASD+DEX group (positive control). Their weights ranged from 18 to $22 \mathrm{~g}$, and there were no significant differences among the groups before starting the study.

The animal studies were performed according to the relevant ethical guidelines and regulations established by the IACUC (Institutional Animal Care and Use Committee of the Institute for Molecules-Based New Drug Development), Approval No. \#IACUC-2018-00124.

\section{Preparation of ASD}

ASD (Yellow soil, Hongikbio, Republic of Korea) samples were purified by heating at $250{ }^{\circ} \mathrm{C}$ for $30 \mathrm{~min}$ and used as the standard base for the samples in this study. The size distribution peaks were observed at 2.6 and $3.9 \mu \mathrm{m}$; according to the manufacturer's description, the chemical elements in ASD consisted of $48.2 \% \mathrm{SiO}_{2}, 34.6 \% \mathrm{Al}_{2} \mathrm{O}_{3}, 13.4 \% \mathrm{Fe}_{2} \mathrm{O}_{3}$, $0.01 \% \mathrm{CaO}, 0.4 \% \mathrm{MgO}, 0.7 \% \mathrm{TiO}_{2}$, and $2.7 \% \mathrm{~K}_{2} \mathrm{O}$. In terms of chemical components, the heavy metal content, and particle sizes, the sand dust purchased was nearly identical to the sand dust collected during the dust storm season in the Republic of Korea.

\section{Experimental protocol}

The experimental protocol was modified from a previous study protocol (Lee et al. 2020). A systemic sensitization step was conducted to establish the OVA-induced asthmatic lung inflammation mouse model. First, $25 \mu \mathrm{g}$ of OVA and $1 \mathrm{mg}$ of alum were mixed with $3 \mathrm{~mL}$ of saline. Then, 150 $\mu \mathrm{L}$ of the mixture was injected into a peritoneal cavity, and 
Fig. 1 Study protocol for asthmatic mouse model. OVA Ovalbumin, $A S D$ Asian sand dust, $B R L$ BRL-50481, DEX dexamethasone, Mch Methacholine, i.t. intratracheal injection, i.p. intraperitoneal injection

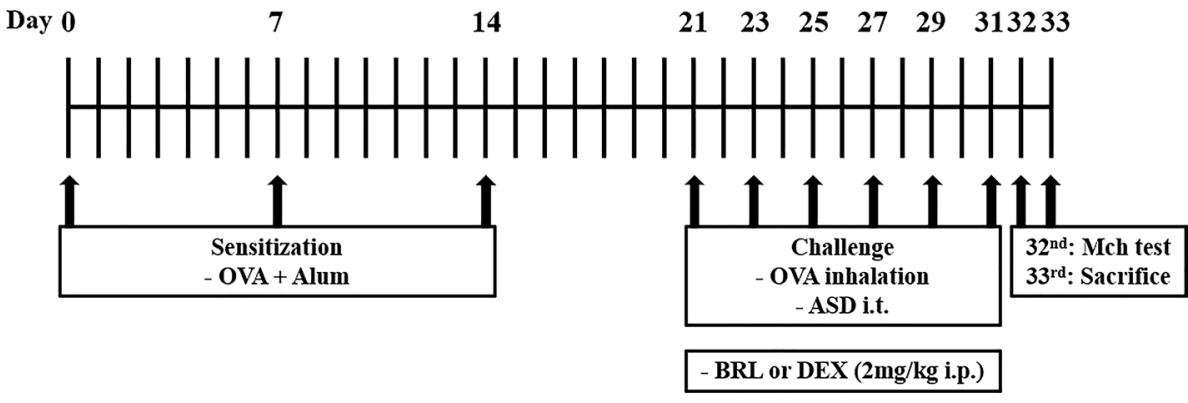

another $150 \mu \mathrm{L}$ was simultaneously injected into subcutaneous cavities of the mouse. Sensitization was performed three times on days 0,7 , and 14 . After sensitization, the OVA, $\mathrm{OVA}+\mathrm{ASD}, \mathrm{OVA}+\mathrm{ASD}+\mathrm{BRL}$, and OVA+ASD+DEX groups were challenged with a $2 \%$ OVA aerosol generated by a nebulizer (Aerogen Pro nebulizer, Aerogen $®$, Galway, Ireland) for $30 \mathrm{~min}$. The control group was exposed to normal saline. BRL or DEX (2 mg/kg, positive control) were administered through intraperitoneal injection (i.p.) $1 \mathrm{~h}$ before the start of the challenge. The mice were anesthetized by intramuscular injection (i.m.) with a mixture of $40 \mathrm{mg} /$ $\mathrm{kg}$ Zoletil ${ }^{\circ} 50$ and $5 \mathrm{mg} / \mathrm{kg}$ xylazine. Then, $1 \mathrm{~h}$ after the end of the aerosol inhalation, $30 \mu \mathrm{L}$ of ASD $(10 \mathrm{mg} / \mathrm{mL})$ was instilled intratracheally (i.t.) in the ASD, OVA+ASD, $\mathrm{OVA}+\mathrm{ASD}+\mathrm{BRL}$, and OVA+ASD+DEX groups. The challenge step was performed every other day from days 21 to 31 for a total of six times. After six challenges, a methacholine test was performed on day 32, and the mice were sacrificed on day 33 (Fig. 1).

\section{Methacholine test}

A methacholine test was performed on day 32 . The specific airway resistance (sRAW) and tidal volume (TV) values were measured to determine the AHR level and the extent to which asthma was induced in mice. The conscious mice were nebulized with $8,16,32,64$, and $128 \mathrm{mg} / \mathrm{mL}$ methacholine for $30 \mathrm{~s}$; the total nebulized volume was $0.02 \mathrm{~mL}$. After nebulizing, sRAW and TV values were measured for 3 min by barometric double-chambered plethysmography (DSI NAM 2-site Station, Buxco®, NC, USA). All measurements were done using a NAM system, and the analyzer was linked to FinePointe Systems Software (Buxco Research Systems, Wilmington, NC, USA).

\section{Bronchoalveolar lavage fluid (BALF) collection and cell counts}

On day 33, the mice were anesthetized with a mixture of $40 \mathrm{mg} / \mathrm{kg}$ Zoletil and $5 \mathrm{mg} / \mathrm{kg}$ xylazine. BALF was collected by flushing the lungs twice with $700 \mu \mathrm{L}$ of ice-cold Dulbecco's Phosphate-buffered Saline (DPBS) and then centrifuged $\left(1500 \times g, 10 \mathrm{~min}, 4{ }^{\circ} \mathrm{C}\right)$. Each supernatant was stored at $-78^{\circ} \mathrm{C}$ for further analysis. The pellet from the BALF was reconstituted with $200 \mu \mathrm{L}$ of RBC lysis buffer (eBioscience $^{\mathrm{TM}} 1 \times$ RBC Lysis Buffer, Invitrogen, Carlsbad, CA, USA) for $10 \mathrm{~min}$ at room temperature and centrifuged at the above-mentioned conditions. After removal of the RBC lysis buffer, the pellet was suspended with $200 \mu \mathrm{L}$ of DPBS and centrifuged again under the same conditions for washing. The pellet was resuspended with $250 \mu \mathrm{L}$ of DPBS, and the total number of inflammatory cells in the BALF was counted with a hemocytometer (Paul Marienfeld GmbH \& Co. KG, Lau-da-Königshofen, Germany). Differential cell counts were performed based on standard morphological criteria with images of staining on glass slides prepared using the Kwik-Diff ${ }^{\text {TM }}$ Stain kit (Thermo Fisher Scientific) after the cytocentrifuge preparation with Cytospin 2 (Thermo Fisher Scientific).

\section{Measurement of cytokine levels in BALF}

BALF levels of IL-4, IL-5, IL-13 levels, TNF- $\alpha$, IL-1 $\beta$, IFN$\gamma$, and MCP-1 were measured using a colorimetric sandwich ELISA kit (Quantikine ${ }^{\circ}$ ELISA, R\&D Systems, MN, USA). The BALF stored at $-78{ }^{\circ} \mathrm{C}$ was used directly for measuring IL-13. The absorbance was measured using a Synergy HTX multimode plate reader (BioTek®, VT, USA).

\section{Quantification of mRNA levels in lung tissue}

The level of mRNA expression was measured in the lung tissue by quantitative reverse transcription PCR (RT-qPCR). Total RNA was isolated from lung tissue using TRIzol® reagent (Ambion ${ }^{\circledR}$, Life Technologies ${ }^{\mathrm{TM}}$, Carlsbad, CA, USA) according to the manufacturer's protocol. After isolating the RNA, an iScript ${ }^{\mathrm{TM}}$ cDNA synthesis kit (Bio-Rad, Hercules, CA, USA) was used to synthesize cDNA by reverse transcription. The cDNA was used for quantitative PCR with specific primers and $\mathrm{iQ}^{\mathrm{TM}} \mathrm{SYBR}{ }^{\circledR}$ green supermix (BioRad, Hercules, CA, USA). Threshold cycle (Ct) values were calculated and used to quantify the relative mRNA levels. The following primer sequences were used for RT-qPCR: 5'-AAAGACACCAGTAGTCACTCAGCAA-3' (forward) 
and 5'- CTGGGAAGTCAG-TGTCAAACCA-3' (reverse) for $M u c 5 a c$ and 5'-CATCACTGCCACCCAGAAGACTG3' (forward) and 5'-ATGCCAGTGAGCTTCCCGTTCAG-3' (reverse) for Gapdh.

\section{Measurement of immunoglobulin level in serum}

Blood samples were obtained from the inferior vena cava, and $40 \mu \mathrm{L}$ of $3.2 \%$ sodium citrate was used as an anticoagulant in each syringe. The obtained blood samples were centrifuged at $1500 \times g$ and $4{ }^{\circ} \mathrm{C}$ for $10 \mathrm{~min}$. The separated serum samples were stored at $-78^{\circ} \mathrm{C}$ and used to measure immunoglobulin levels. OVA-specific IgE and IgG1 (Cayman Chemical, Ann Arbor, MI, USA) enzyme-linked immunosorbent assay (ELISA) kits were used according to the manufacturer's instructions.

\section{Histopathological analysis of lung tissue}

For histopathologic analysis, lung tissue samples were fixed using 10\% neutral phosphate-buffered formalin and embedded in paraffin using the Tissue-Tek® TECTM 5 Tissue Embedding Console System (Sakura Finetek $®$, Torrance, CA, USA). The embedded lung tissue samples were sectioned at 4- $\mu \mathrm{m}$ thickness and stained with hematoxylin and eosin (H\&E) to visualize the degree of inflammatory cell infiltration, other inflammatory responses, and pathological changes in the lung tissue. The degree of inflammation in the lung tissues was determined using the histologic grading criteria (Curtis et al. 1990) with $0=$ no inflammation, $1=$ occasional cuffing with inflammatory cells, $2=$ most bronchi or vessels surrounded by a thin layer (1-5 cells) of inflammatory cells, and $3=$ most bronchi or vessels surrounded by a thick layer ( $>5$ cells) of inflammatory cells. The sections were also stained with periodic acid-Schiff (PAS) to evaluate the mucin production in the bronchial epithelium. Mucus secretion was evaluated by measuring area fraction of redstained regions in the bronchoalveolar tissue using ImageJ software. Each stained tissue section was observed under a microscope (Leica Microsystems, Wetzlar, Germany), and images were taken with a Leica DM 480 camera.

\section{cAMP assay}

The cAMP level was measured in liver tissue using a cAMP assay kit (abcam ${ }^{\circledR}$, Cambridge, UK). The lung tissues were frozen in liquid nitrogen and stored at $-78^{\circ} \mathrm{C}$. The tissues were lysed using a homogenizer, and then centrifuged $\left(1500 \times g, 10 \mathrm{~min}, 4{ }^{\circ} \mathrm{C}\right)$. The collected supernatants were used for the cAMP assay. The absorbance was measured using a microplate reader $(B i o T e k \AA$, VT, USA).

\section{Immunofluorescence}

The sections were stained with a fluorescein isothiocyanate (FITC)-conjugated anti-MUC5 AC antibody (Santa Cruz Biotechnology, TX, USA) to evaluate MUC5AC production in the bronchial epithelium. Each stained tissue section was observed under a microscope (Leica Microsystems, Wetzlar, Germany), and images were taken with a Leica DM 480 camera.

\section{Statistical analysis}

All values are presented as a mean \pm standard error of the mean $(\mathrm{SEM})$ of data $(\mathrm{n}=10)$. Statistical analysis was performed using one-way and two-way ANOVA. Differences among groups were determined as statistically significant at $\mathrm{P}<0.05$ and $\mathrm{P}<0.01$.

\section{Results}

\section{Effect of BRL on AHR}

A methacholine test was performed to measure the AHR level. The sRAW, an indicator metric of AHR, increased in a dose-dependent manner after methacholine application. Airway resistance was significantly increased in the OVA group $(151.1 \pm 4.5 \%)(\mathrm{P}<0.01)$ and the OVA+ASD group $(166.4 \pm 8.6 \%)(\mathrm{P}<0.001)$ at $128 \mathrm{mg} / \mathrm{mL}$ of methacholine. Furthermore, the sRAW level of the OVA+ASD group was also significantly higher than that of the OVA group $(\mathrm{P}<0.01)$, which suggests that ASD exacerbated AHR. The elevation in sRAW was significantly decreased in the OVA+ASD+BRL group $(133.3 \pm 9.9 \%)(\mathrm{P}<0.001)$ and the OVA+ASD+DEX group $(134.1 \pm 8.7 \%)(\mathrm{P}<0.001)$, which served as a positive control (Fig. 2A). There was no significant difference in TV among the groups (Fig. 2B).

\section{Effect of BRL on inflammatory cell infiltration}

To measure the infiltration of inflammatory cells into the lungs, BALF was collected, and inflammatory cells were counted (Fig. 3A). There was a significant increase in the total number of inflammatory cells in the OVA group (31.0 $[ \pm 9.8] \times 10^{4}$ cells $)(\mathrm{P}<0.05)$ and OVA+ASD group $(66.3$ $[ \pm 7.7] \times 10^{4}$ cells $)(\mathrm{P}<0.01)$ compared to the control group $\left(2.0[ \pm 0.3] \times 10^{4}\right.$ cells $)$. Furthermore, the total number of inflammatory cells increased significantly in the OVA+ASD group compared to the OVA group $(\mathrm{P}<0.05)$. The cell counts in the OVA+ASD+BRL group $\left(32.1[ \pm 10.3] \times 10^{4}\right.$ cells $)(\mathrm{P}<0.05)$ and the OVA+ASD+DEX group $(29.3[ \pm$ $6.7] \times 10^{4}$ cells $)(\mathrm{P}<0.01)$ were significantly lower than those in the OVA+ASD group but comparable to those in 

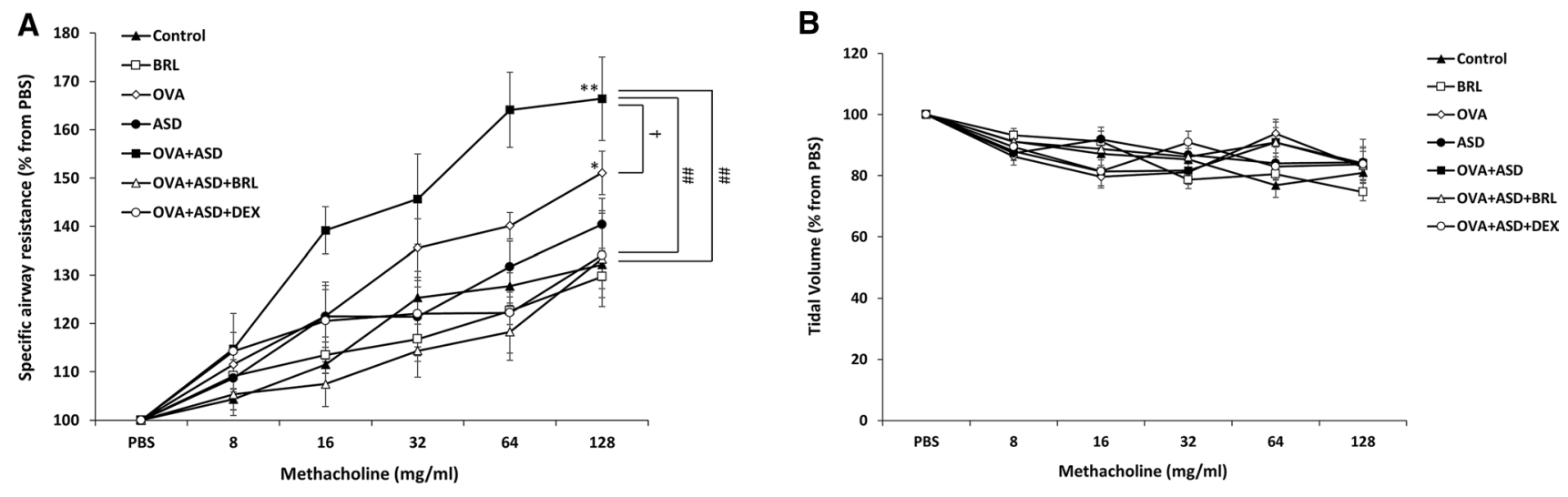

Fig. 2 Measurement of AHR by methacholine test. sRAW (A) and TV (B) were measured by barometric double-chambered plethysmography (DSI NAM 2-site Station, Buxco®, NC, USA). All measurements were made using a NAM system and an analyzer (FinePointe Systems Software Buxco Research Systems, Wilmington, NC, USA). * and ** represent significant differences from the control group $(* \mathrm{P}<0.01$, $* * \mathrm{P}<0.001) .{ }^{\#}$ and ${ }^{\# \#}$ represent significant differences from the OVA+ASD group $\left({ }^{\#} \mathrm{P}<0.01,{ }^{\# \#} \mathrm{P}<0.001\right) .{ }^{\dagger}$ and ${ }^{\dagger \dagger}$ represent significant differences between the OVA and the OVA+ASD group $\left({ }^{\dagger} \mathrm{P}<0.01,{ }^{\dagger} \mathrm{P}<0.001\right)$. BRL BRL-50481, OVA Ovalbumin, ASD Asian sand dust, DEX Dexamethasone, $s R A W$ specific airway resistance, $T V$ tidal volume, $N A M$ noninvasive airway mechanics

the OVA group (Fig. 3B). Differentiated inflammatory cells were also counted, and macrophage and eosinophil numbers were decreased in in the OVA+ASD+BRL group and the OVA+ASD+DEX group. BRL and DEX did not cause any decrease in neutrophil counts (Fig. 3C).

\section{Effect of BRL on IL-13 level in BALF}

Concentrations of interleukin (IL)-13 were analyzed using the ELISA kit to investigate the signaling processes in asthmatic lung inflammation and the role of IL-13 in mucin production. IL-13 levels were significantly increased in the OVA group $(13.2 \pm 3.2 \mathrm{pg} / \mathrm{mL})(\mathrm{P}<0.05)$ and the OVA+ASD group $(22.9 \pm 2.7 \mathrm{pg} / \mathrm{mL})(\mathrm{P}<0.01)$ compared to the control group $(2.8 \pm 0.2 \mathrm{pg} / \mathrm{mL})$. Furthermore, the IL-13 level of the OVA+ASD group was also significantly increased compared to the OVA group $(\mathrm{P}<0.05)$, which suggests that ASD exacerbated inflammation signaling. The IL-13 level significantly decreased in the OVA+ASD+BRL group $(7.6 \pm 1.4 \mathrm{pg} / \mathrm{mL})$ $(\mathrm{P}<0.01)$ and the OVA+ASD+DEX group $(6.8 \pm 1.5 \mathrm{pg} /$ $\mathrm{mL})(\mathrm{P}<0.01)$ (Fig. 4). There were no significant differences in IL-4 and IL-5 levels among the groups (data not shown).

\section{Effect of BRL on cytokine and chemokine levels in BALF}

TNF- $\alpha$ levels were significantly increased in the OVA+ASD group $(25.9 \pm 1.4 \mathrm{pg} / \mathrm{mL})(\mathrm{P}<0.01)$ compared to the control group $(2.9 \pm 0.1 \mathrm{pg} / \mathrm{mL})$. In contrast, the TNF- $\alpha$ level had significantly decreased in the OVA+ASD+BRL group $(2.8 \pm 0.1 \mathrm{pg} / \mathrm{mL})(\mathrm{P}<0.01)$ and the OVA+ASD+DEX group $(3.4 \pm 0.1 \mathrm{pg} / \mathrm{mL})(\mathrm{P}<0.01)$ (Fig. 5A). Similarly, the MCP-1 levels were significantly increased in the OVA group $(43.3 \pm 3.4 \mathrm{pg} / \mathrm{mL})(\mathrm{P}<0.01)$ and OVA+ASD group $(154.0 \pm 6.0 \mathrm{pg} / \mathrm{mL})(\mathrm{P}<0.001)$ compared to the control group $(3.3 \pm 0 \mathrm{pg} / \mathrm{mL})$. Furthermore, the MCP-1 level of the OVA+ASD group was significantly higher than that of the OVA group $(\mathrm{P}<0.01)$. However, the MCP-1 level had significantly decreased in the OVA+ASD+BRL group $(26.7 \pm 0.1 \mathrm{pg} / \mathrm{mL})(\mathrm{P}<0.001)$ and the OVA+ASD+DEX group $(11.4 \pm 0.1 \mathrm{pg} / \mathrm{mL})(\mathrm{P}<0.001)$ (Fig. 5B). There were no significant differences in the IL-1 $\beta$ and INF- $\gamma$ levels among the groups (data not shown).

\section{Effect of BRL on immunoglobulin level in serum}

Immunoglobulin levels were analyzed using the ELISA kits to investigate the degree of systemic allergy and inflammation. OVA-specific IgE levels were significantly increased in the OVA group $(40.7 \pm 15.3 \mathrm{ng} / \mathrm{mL})(\mathrm{P}<0.05)$ and the OVA+ASD group $(83.1 \pm 13.6 \mathrm{ng} / \mathrm{mL})(\mathrm{P}<0.01)$ compared to the control group $(0.4 \pm 0.1 \mathrm{ng} / \mathrm{mL})$. Moreover, the OVA-specific IgE level of the OVA+ASD group was significantly higher than that of the OVA group, although the difference was not significant. In contrast, the OVA-specific IgE level was significantly lower in the OVA+ASD+BRL group $(29.4 \pm 7.5 \mathrm{ng} / \mathrm{mL})(\mathrm{P}<0.05)$ and OVA+ASD+DEX group $(36.1 \pm 11.9 \mathrm{ng} / \mathrm{mL})(\mathrm{P}<0.05)$ (Fig. 6A). Similarly, the OVA-specific IgG1 level was significantly higher in the OVA group $(67.9 \pm 10.5 \mathrm{ng} / \mathrm{mL})(\mathrm{P}<0.01)$ and OVA+ASD group $(116.0 \pm 5.6 \mathrm{ng} / \mathrm{mL})(\mathrm{P}<0.01)$ than the control group $(1.4 \pm 0.1 \mathrm{ng} / \mathrm{mL})$. Furthermore, the OVA-specific IgG1 level of the OVA+ASD group was significantly higher than that of the OVA group $(\mathrm{P}<0.05)$. The OVA-specific IgG1 level had significantly decreased in the OVA+ASD+BRL 
A

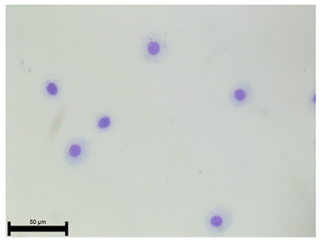

Control

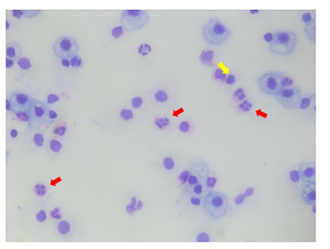

OVA

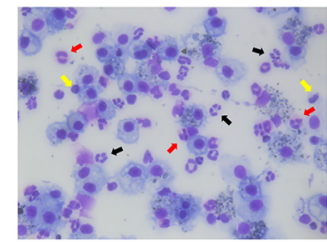

OVA+ASD

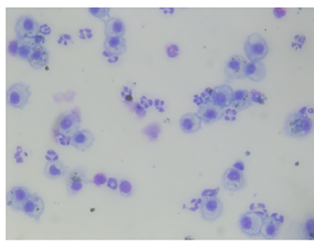

OVA+ASD+DEX
B

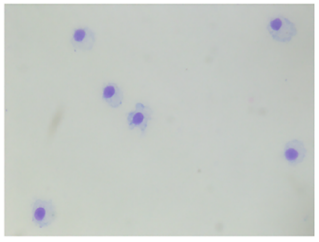

BRL

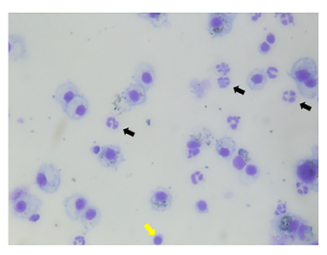

ASD

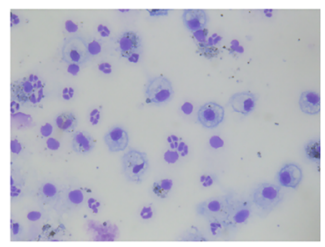

$O V A+A S D+B R L$

C
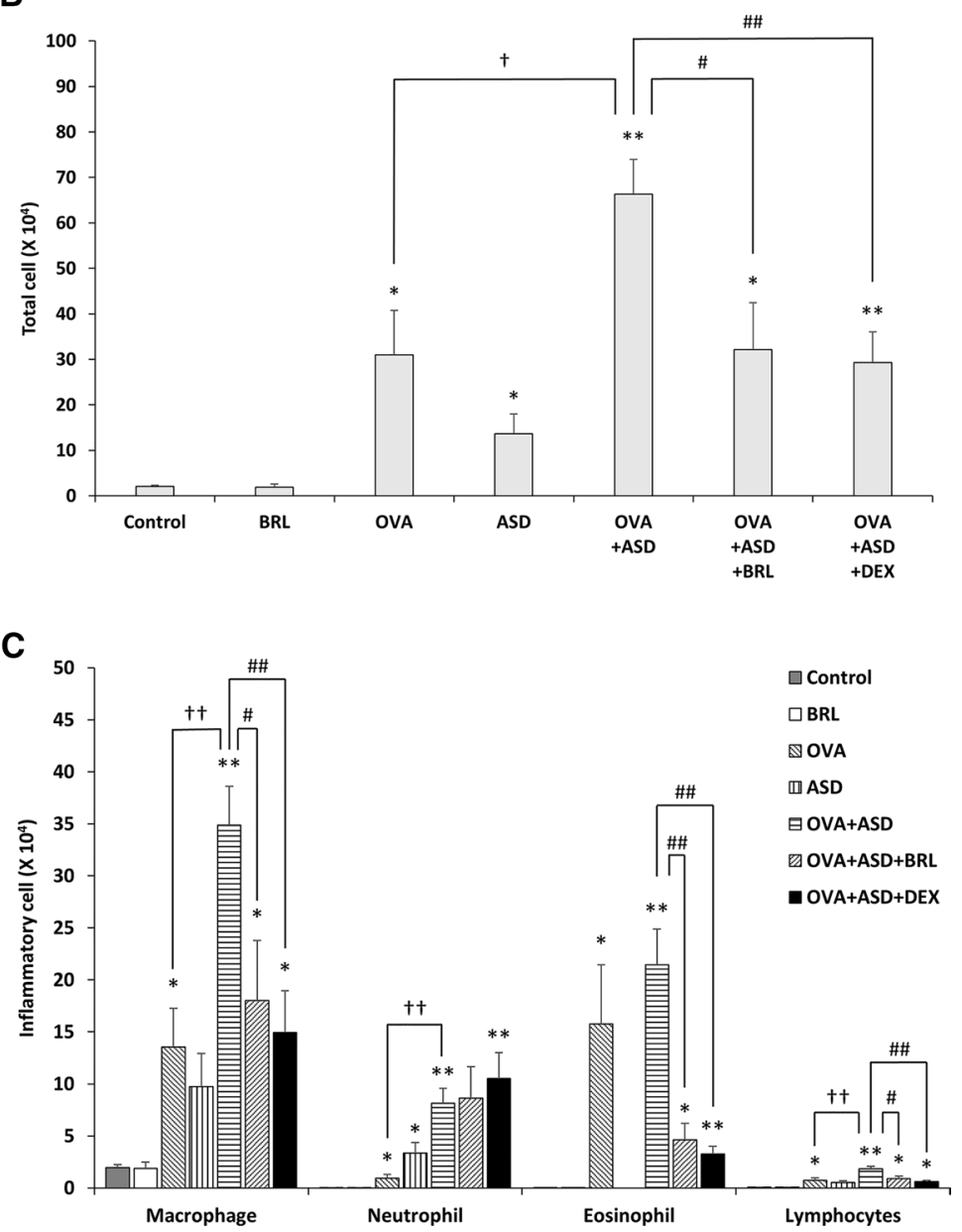

Fig. 3 Infiltration of inflammatory cells in BALF. Inflammatory cells were stained using the KWIK-DIFFTM stain kit, Shandon, Thermo Scientific, MA, USA (A). Red arrows indicate eosinophils, black arrows indicate neutrophils, and yellow arrows indicate lymphocytes. Images were obtained using a Leica DM 480 camera (Leica Microsystems, Wetzlar, Germany, magnification $\times 400$, scale bars $=50 \mu \mathrm{m})$. Total cells $(\mathbf{B})$ and differentiated inflammatory cells $(\mathbf{C})$ in BALF were counted in the images using a hemocytometer. $*$ and $* *$ represent significant differences from the control group $\left(* \mathrm{P}<0.05,{ }^{* *} \mathrm{P}<0.01\right) .{ }^{\#}$ and ${ }^{\# \#}$ represent significant differences from the OVA+ASD group $\left({ }^{\#} \mathrm{P}<0.05,{ }^{\# \#} \mathrm{P}<0.01\right) .{ }^{\dagger}$ and ${ }^{\dagger \dagger}$ represent significant differences between the OVA and the OVA+ASD group $\left({ }^{\dagger} \mathrm{P}<0.05,{ }^{\dagger \dagger} \mathrm{P}<0.01\right)$. BRL BRL-50481, OVA ovalbumin, ASD Asian sand dust, $D E X$ dexamethasone

group $(64.0 \pm 10.7 \mathrm{ng} / \mathrm{mL})(\mathrm{P}<0.01)$ and $\mathrm{OVA}+\mathrm{ASD}+\mathrm{DEX}$ group $(69.1 \pm 7.6 \mathrm{ng} / \mathrm{mL})(\mathrm{P}<0.01)$ (Fig. 6B).

\section{Effect of BRL on histopathological changes in lung tissue}

H\&E staining was performed to visualize and monitor histological changes, and inflammation scores were determined. There was an infiltration of macrophages and eosinophils in the OVA, ASD, and OVA+ASD groups, and the inflammation scores were significantly increased in these groups $(\mathrm{P}<0.01)$. Furthermore, the inflammation score of OVA+ASD $(2.6 \pm 0.2)$ was also significantly higher than that of the OVA $(2.0 \pm 0.1)$ group $(\mathrm{P}<0.05)$, which suggests that ASD exacerbated OVA-induced lung inflammation. The increase in the inflammation score significantly decreased in the OVA+ASD+BRL group $(1.5 \pm 0.2)(\mathrm{P}<0.05)$ and the OVA+ASD+DEX group $(1.4 \pm 0.3)(\mathrm{P}<0.05)($ Fig. 7$)$.

\section{Effect of BRL on mucin production in lung tissue}

PAS staining was performed to monitor mucin production and goblet cell proliferation. The PAS-positive area was also measured using ImageJ software. Hypersecretion of mucin and the PAS-positive area were significantly higher in the OVA group $(7.1 \pm 1.5 \%)$ and the OVA+ASD group $(16.2 \pm 2.2 \%)(\mathrm{P}<0.01)$. Furthermore, mucin production of the OVA+ASD group also increased significantly compared to the OVA group $(\mathrm{P}<0.01)$, suggesting that ASD exacerbated OVA-induced mucin production. The 


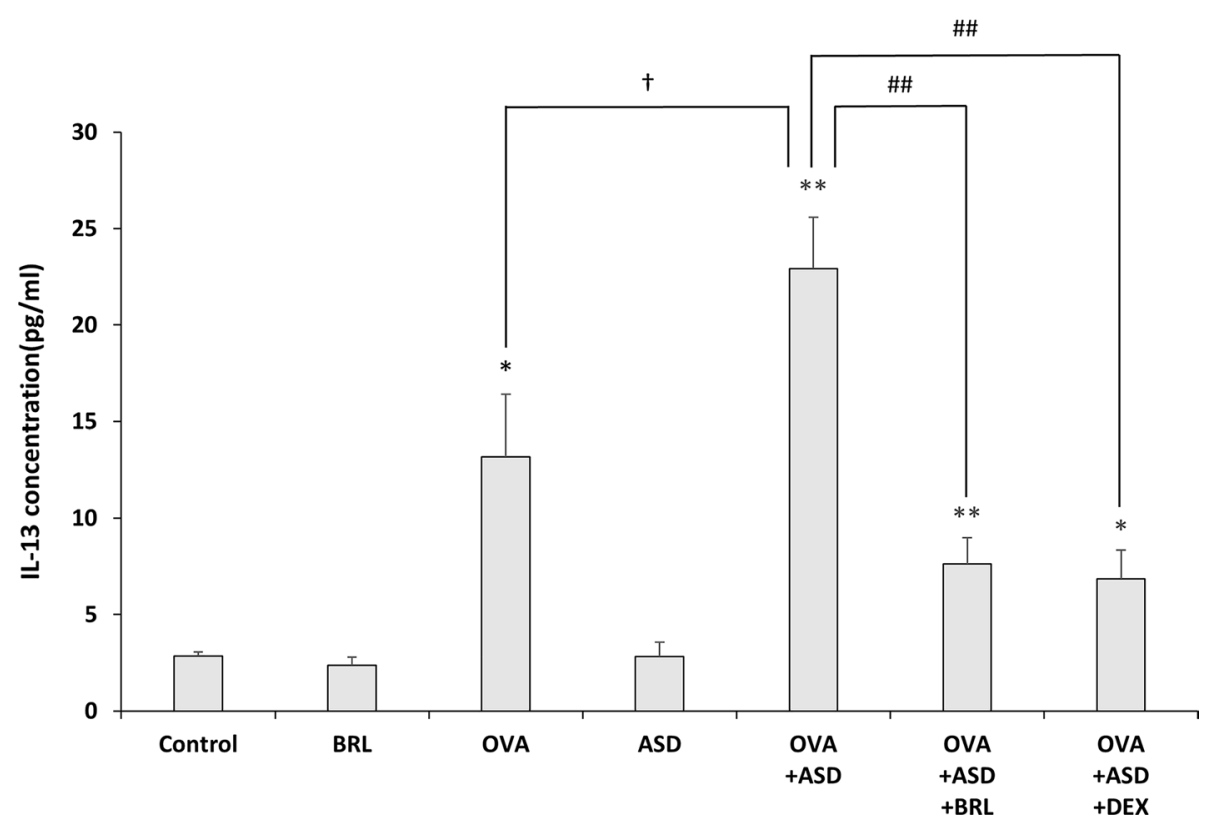

Fig. 4 Th2-mediated cytokine IL-13 level in BALF. IL-13 level was measured in BALF using an ELISA kit. * and ** represent significant differences from the control group $(* \mathrm{P}<0.05, * * \mathrm{P}<0.01)$. ${ }^{\#}$ and ${ }^{\# \#}$ represent significant differences from the OVA+ASD group $\left({ }^{\#} \mathrm{P}<0.05\right.$, $\left.{ }^{\# \#} \mathrm{P}<0.01\right) .{ }^{\dagger}$ and ${ }^{\dagger \dagger}$ represent significant differences between the OVA and the OVA+ASD group $\left({ }^{\dagger} \mathrm{P}<0.05,{ }^{\dagger \dagger} \mathrm{P}<0.01\right) .8 R L$ BRL-50481, Th2: T helper 2 cell, OVA Ovalbumin, ASD Asian sand dust, DEX Dexamethasone, BALF Bronchoalveolar lavage fluid
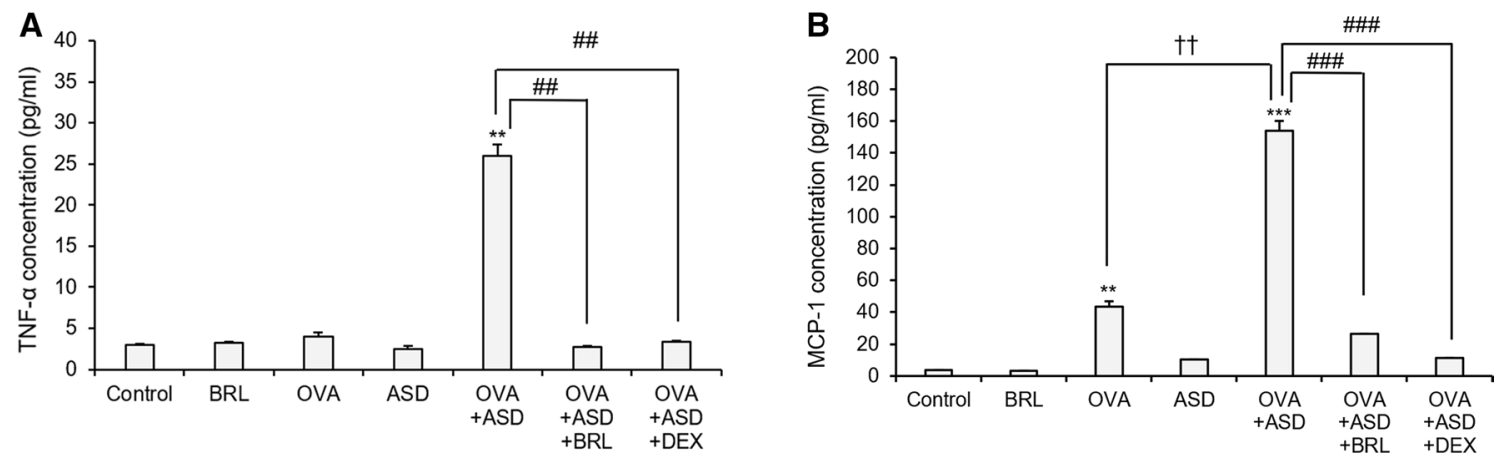

Fig. 5 Cytokine and chemokine levels in BALF. TNF- $\alpha(\mathbf{A})$, and MCP-1 (B) in BALF were measured using ELISA kits. ** and *** represent significant differences from the control group $(* * \mathrm{P}<0.01$, *** $\mathrm{P}<0.001) .{ }^{\# \#}$ and ${ }^{\# \#}$ \# represent significant differences from the OVA+ASD group $\left({ }^{\# \#} \mathrm{P}<0.01,{ }^{\# \# \#} \mathrm{P}<0.001\right) .{ }^{\dagger \dagger}$ represent significant differences between the OVA and the OVA+ASD group $\left({ }^{\dagger \dagger} \mathrm{P}<0.01\right) . B R L$ BRL-50481, OVA Ovalbumin, $A S D$ Asian sand dust, $D E X$ Dexamethasone, $B A L F$ Bronchoalveolar lavage fluid, $T N F$ - $\alpha$ : tumor necrosis factor-alpha, $M C P-1$ monocyte chemoattractant protein-1, ELISA enzyme-linked immunosorbent assay

increase in mucin secretion was significantly decreased in the OVA+ASD+BRL group $(1.7 \pm 0.8 \%)(\mathrm{P}<0.01)$ and the OVA+ASD+DEX group $(1.2 \pm 0.5 \%)(\mathrm{P}<0.01)$ (Fig. 8).

Immunofluorescence (IF) analysis was performed to observe MUC5AC production. MUC5AC was labeled green by the FITC-conjugated antibody and determined by ImageJ software. MUC5AC production was significantly higher in the OVA+ASD group $(7.0 \pm 1.5 \%)(\mathrm{P}<0.05)$ and significantly lower in the OVA+ASD+BRL group $(0.7 \pm 0.1 \%)$ $(\mathrm{P}<0.01)$ and the OVA+ASD+DEX group $(0.9 \pm 0.5 \%)$ $(\mathrm{P}<0.05)$ (Fig. 9A, B).
The Muc5ac mRNA level was analyzed by RT-qPCR and found to be significantly increased in the OVA group $(2.6 \pm 0.4$-fold compared to the control $)(\mathrm{P}<0.01)$ and OVA+ASD group $(4.7 \pm 0.7$-fold compared to the control) $(\mathrm{P}<0.01)$. Furthermore, the Muc5ac mRNA level of the OVA+ASD group was significantly higher than that of the OVA group $(\mathrm{P}<0.05)$. The elevation of the Muc5ac mRNA level significantly decreased in the OVA+ASD+BRL group $(2.3 \pm 0.4$-fold compared to control $)(\mathrm{P}<0.05)$ and the OVA+ASD+DEX group $(1.7 \pm 0.3$-fold compared to the control) $(\mathrm{P}<0.01)$ (Fig. 9c). 

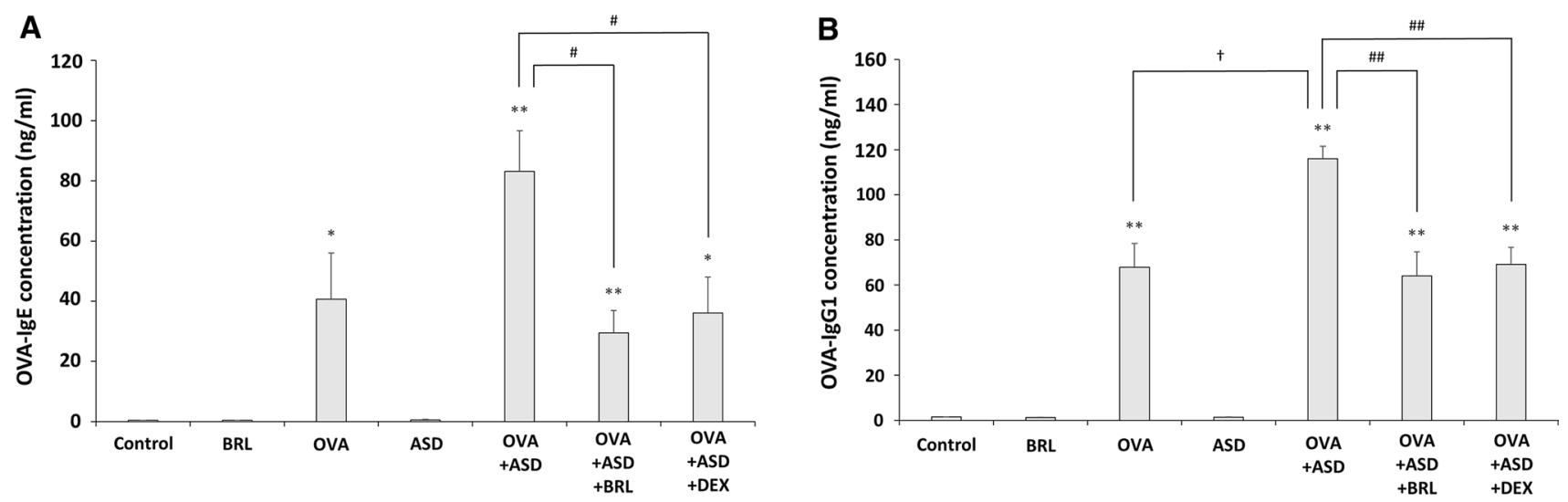

Fig. 6 OVA-specific IgE and IgG1 levels in serum. OVA-specific IgE (A) and IgG1 (B) levels in serum were measured using ELISA kits. * and $* *$ represent significant differences from the control group $(* \mathrm{P}<0.05, * * \mathrm{P}<0.01) .{ }^{*}$ and ${ }^{\# \#}$ represent significant differences from the OVA+ASD group $\left({ }^{\#} \mathrm{P}<0.05,{ }^{\# \#} \mathrm{P}<0.01\right) .{ }^{\dagger}$ and ${ }^{\dagger \dagger}$ represent significant differences between the OVA and the OVA+ASD group $\left({ }^{\dagger} \mathrm{P}<0.05,{ }^{\dagger \dagger} \mathrm{P}<0.01\right) . B R L$ BRL-50481, OVA ovalbumin, ASD Asian sand dust, DEX dexamethasone, I $g$ immunoglobulin, ELISA enzyme-linked immunosorbent assay

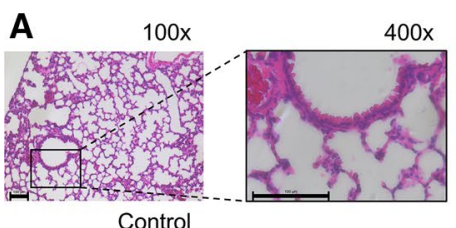

Control

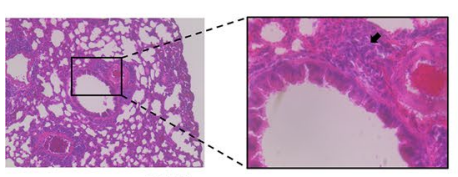

OVA

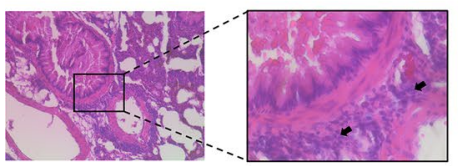

OVA+ASD

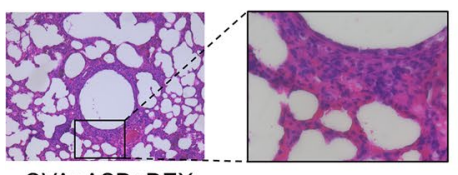

OVA+ASD+DEX

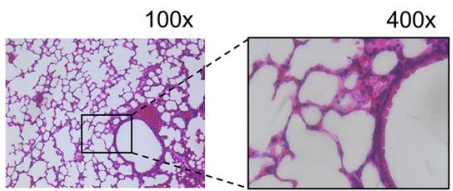

$\mathrm{BRL}$

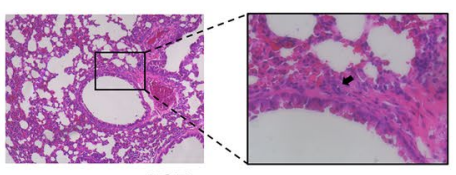

ASD

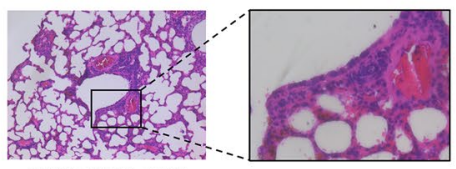

OVA+ASD+BRL

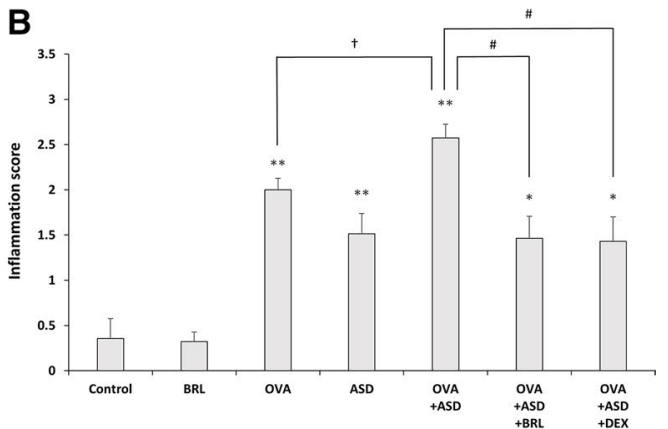

Fig. $7 \mathrm{H} \& \mathrm{E}$ staining of ASD-exacerbated asthmatic lung tissue. Black arrows indicate infiltration of inflammatory cells (magnification $\times 100$, scale bars: $100 \mu \mathrm{m}$ in the left column, $\times 400$, scale bars: $100 \mu \mathrm{m}$ in the right column) $(\mathbf{A})$. The inflammation scores were determined based on histologic grading criteria $(\mathbf{B})$. ${ }^{*}$ and $* *$ represent significant differences from the control group $\left(* \mathrm{P}<0.05,{ }^{* *} \mathrm{P}<0.01\right)$. ${ }^{\#}$ and ${ }^{\# \#}$ represent significant differences from the OVA+ASD group $\left({ }^{\#} \mathrm{P}<0.05,{ }^{\# \#} \mathrm{P}<0.01\right) .{ }^{\dagger}$ and ${ }^{\dagger \dagger}$ represent significant differences between the OVA and the OVA+ASD group $\left({ }^{\dagger} \mathrm{P}<0.05,{ }^{\dagger \dagger} \mathrm{P}<0.01\right) . H \& E$ hematoxylin and eosin, BRL BRL-50481, OVA ovalbumin, $A S D$ Asian sand dust, DEX dexamethasone

\section{Discussion}

In this study, the effects of the administration of a PDE7 inhibitor in a mouse model were investigated along with co-exposure to ASD, which exacerbated OVA-induced asthmatic lung inflammation. Sensitization and the challenge with OVA increased AHR, infiltration of inflammatory cells into the lung, and IL-13, immunoglobulin, and mucin production. These results suggest that OVA allergen exposure leads to asthmatic lung disease. Furthermore, all these allergic responses were exacerbated in a synergistic manner by ASD co-exposure. These results are consistent with those of 

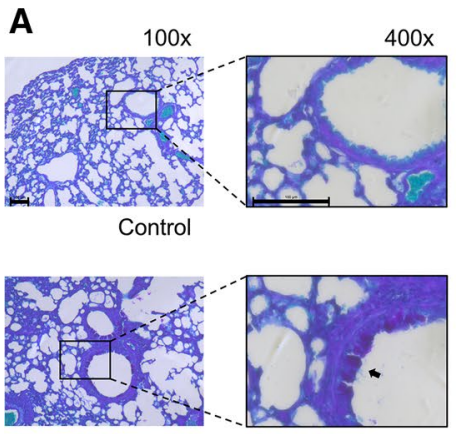

OVA

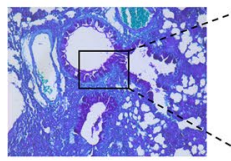

OVA+ASD
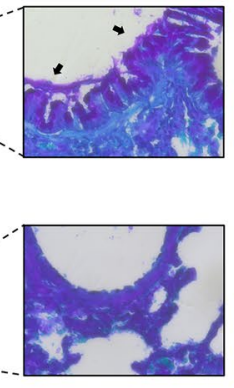

OVA+ASD+DEX

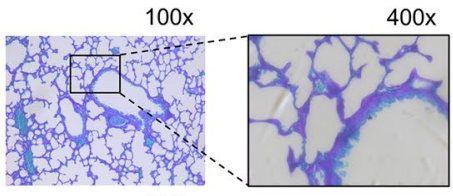

$\mathrm{BRL}$

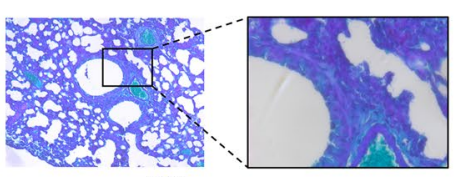

ASD

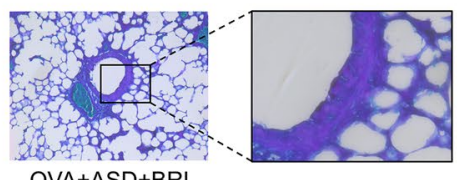

OVA+ASD+BRL

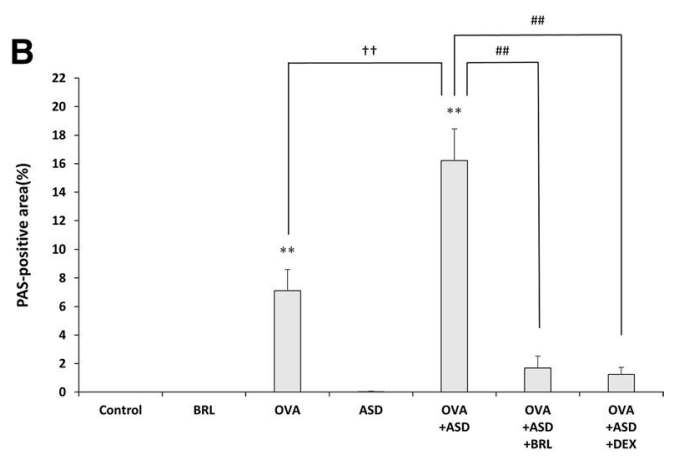

Fig. 8 PAS staining of ASD-exacerbated asthmatic lung tissue. Black arrows indicate hypersecretions of mucin (magnification $\times 100$, scale bars: $100 \mu \mathrm{m}$ in the left column, $\times 400$, scale bars: $100 \mu \mathrm{m}$ in the right column) (A). PAS-positive area in HPF was determined by ImageJ software $(\mathbf{B})$. * and $* *$ represent significant differences from the control group $(* \mathrm{P}<0.05, * * \mathrm{P}<0.01)$. ${ }^{*}$ and ${ }^{\# \#}$ represent significant differences from the OVA+ASD group $\left({ }^{\#} \mathrm{P}<0.05,{ }^{\# \#} \mathrm{P}<0.01\right) .{ }^{\dagger}$ and ${ }^{\dagger \dagger}$ represent significant differences between the OVA and the OVA+ASD group $\left({ }^{\dagger} \mathrm{P}<0.05\right.$, $\left.{ }^{\dagger} \mathrm{P}<0.01\right)$. PAS Periodic acid-Schiff, BRL BRL-50481, OVA Ovalbumin, ASD Asian sand dust, $D E X$ dexamethasone, $H P F$ high-power field

a previous study reporting that ASD enhanced several diseases, such as asthma (Honda et al. 2017), atopic dermatitis (Takeshita et al. 2015), and pneumonia (He et al. 2012), in a murine model.

Meanwhile, ASD-exacerbated lung inflammation was significantly ameliorated by the administration of the PDE7 inhibitor BRL-50481. BRL significantly alleviated AHR; infiltration of inflammatory cells into the lung; production of proinflammatory cytokines such as IL-13, MCP-1, and TNF- $\alpha$; and the production of mucin and antigen-specific immunoglobulins such as IgE and IgG1. However, BRL did not reduce the inflammatory factors to normal levels or levels similar to or below those of the OVA group. These results suggest that BRL could reduce ASD-exacerbated, allergy-induced lung inflammation. This may be due to the effects of the PDE7 inhibitor on T lymphocytes (Page 2014), which are the main producers of IL-13 (Zurawski and de Vries 1994). Many studies suggest that PDE7 inhibitors could be used as anti-inflammatory drugs to treat chronic obstructivege pulmonary disease (Fortin et al. 2009), smooth muscle constriction, cough (Mokry et al. 2013), hepatitis, endotoxemia, arthritis, and encephalomyelitis (Rucilova et al. 2020).

IL-13 production in the airway is involved in the survival and migration of eosinophils, activation of macrophages,
AHR, production of inducible nitric oxide synthase by airway epithelial cells, and especially goblet cell metaplasia with mucus hypersecretion (Ingram and Kraft 2012). Airway mucus, secreted by the submucosal glands and goblet cells, protects the underlying epithelium by trapping potentially harmful inhaled particles and pathogens (Kim 1997). Mucus hypersecretion, frequently observed in asthma patients and especially in severe disease, has been associated with chronic upper airway disease, poor asthma control, and a greater degree of exacerbation (Martínez-Rivera et al. 2018).

In the current study, PAS staining showed a significant increase in mucin production in the OVA+ASD group, while ELISA results revealed a similar trend in the IL-13 level. The mRNA level of Muc5ac in the OVA+ASD group was significantly increased, suggesting that mucin hypersecretion is due to the increase in MUC5AC. IL-13 increases the expression of $M u c 5 a c$, leading to mucus hypersecretion (Seibold 2018). A previous study also reported that IL-13 stimulates conjunctival goblet cell proliferation and MUC5AC production (Tukler Henriksson et al. 2015). However, the genes and mechanisms by which these transcription factors drive IL-13-induced mucus metaplasia and increase Muc5ac expression are poorly understood (Seibold 2018). In vitro studies on human airway epithelial cells have shown that there are two mechanisms of IL-13 regulating Muc5ac 
A

Control

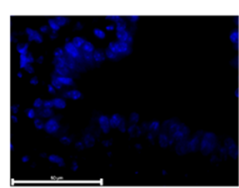

BRL
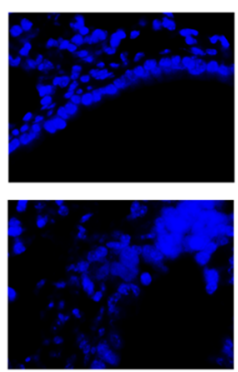

OVA

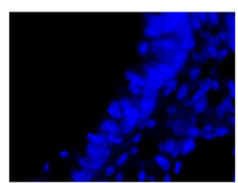

ASD

OVA

+ASD
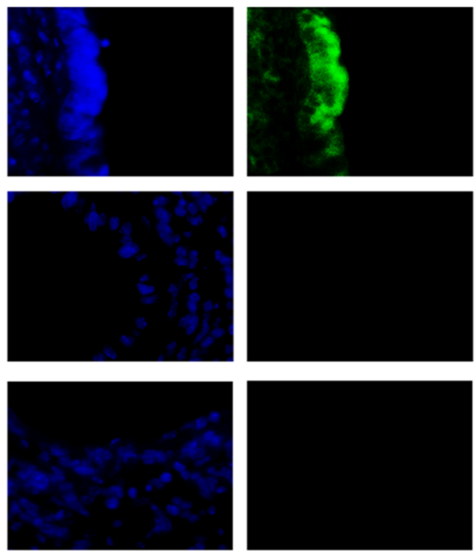

MUC5AC
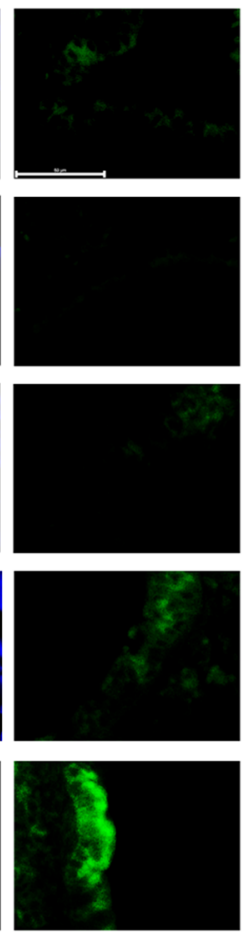

OVA
+ ASD
+ BRL

OVA

+ ASD

+ DEX

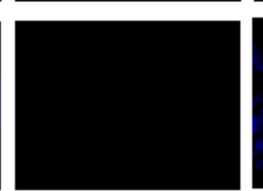

MERGE
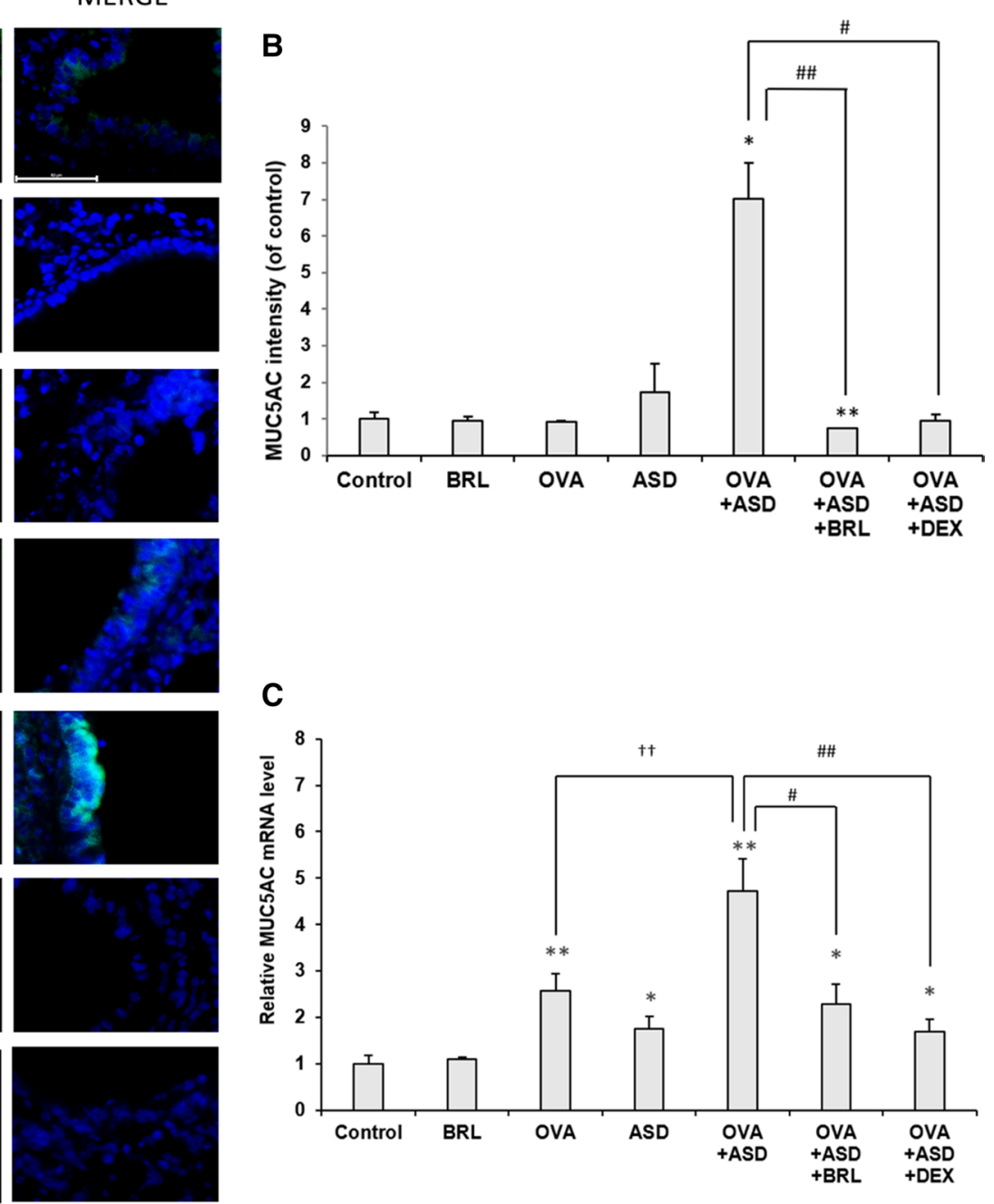

Fig. 9 MUC5AC production in ASD-exacerbated asthmatic lung tissue. FITC-conjugated antibody detected MUC5AC (magnification $\times 1600$, scale bars: $50 \mu \mathrm{m})(\mathbf{A})$. The intensity of green fluorescence was measured by ImageJ software $(\mathbf{B})$. The mRNA levels of Muc5ac in lung tissue were measured by RT-qPCR $(\mathbf{C})$. * and $* *$ represent significant differences from the control group $(* \mathrm{P}<0.05, * * \mathrm{P}<0.01)$. ${ }^{\#}$ and ${ }^{\# \#}$ represent significant differences from the OVA+ASD group $\left({ }^{\#} \mathrm{P}<0.05,{ }^{\# \#} \mathrm{P}<0.01\right) .{ }^{\dagger}$ and ${ }^{\dagger \dagger}$ represent significant differences between the OVA and the OVA+ASD group $\left({ }^{\dagger} \mathrm{P}<0.05,{ }^{\dagger} \mathrm{P}<0.01\right)$. FITC fluorescein isothiocyanate, BRL BRL-50481, OVA Ovalbumin, ASD Asian sand dust, DEX Dexamethasone

expression. Specifically, the enzymatic activity of arachidonate 15-lipoxygenase (ALOX15) in generating 15-hydroxyeicosatetraenoic acid species has been implicated in IL13-based MUC5AC expression, while extracellular signaling by chloride channel accessory 1 (CLCA1) protein has been found to drive MUC5AC expression through the activation of mitogen-activated protein kinase (MAPK) signaling (Zhao et al. 2009; Alevy et al. 2012).

Notably, PAS staining did not reveal any increase in mucin production in the ASD group despite the infiltration of inflammatory cells, a result that is in agreement with that of a previous study (Kang et al. 2012). This suggests that ASD may not induce allergy on its own and may act as an adjuvant or cofactor in allergic inflammation.
This study differs from others because we found no significant differences between IL-4 and IL-5. Nevertheless, IL-13 induced asthmatic lung inflammation, which was synergistically exacerbated by ASD, and there was a characteristic overexpression of mucin. A previous study had reported that transgenic overexpression of $I L-13$ alone in the airways of mice caused an asthmatic inflammatory response characterized by inflammatory cell infiltration, goblet cell hyperplasia, mucus hyperproduction, and AHR (Zhu et al. 1999). BRL alleviated ASD-driven exacerbation by reducing IL-13 levels. However, other signaling mechanisms between mucin and PDE7 is unclear, and further studies are needed to investigate PDE7 inhibitors as treatments for asthma. 
Interestingly, the concentration of cAMP in lung tissue significantly decreased in all BRL-treated groups (Supplementary 1). Based on the evidence from other reports, there is an increase in cAMP concentration with short-term (2 min) treatment with a PDE4 inhibitor rolipram. However this elevation in cAMP concentration with long-term treatment $(>8 \mathrm{~h})$ with rolipram increased the expression and activity of PDE4, which speed up cAMP degradation in HUVEC cells (Lugnier et al. 2021). Furthermore, the increase in cAMP concentration with treatment with forskolin, IBMX, or db-cAMP reduced IL-4, IL-5, IL-13 production through the inhibition of $\mathrm{T}$ cell activation (Borger et al. 1996; Grader-Beck et al. 2003). Thus, the decrease in cAMP concentration in the lung tissue of BRL-treated groups might be due to the long-term treatment with BRL in the 33-day experimental protocol. Moreover, the antiinflammatory effect of BRL seems to depend on T cell inactivation due to an increase in the cAMP concentration in the early phase, which, in turn, could lead to the inhibition of Th2mediated production of proinflammatory cytokines such as IL-13, TNF- $\alpha$, and MCP-1. However, further study is needed on cAMP-PDE activity cellular signaling mediated by BRL because this was not the focus of this study.

In conclusion, this study demonstrated that BRL, a selective PDE7 inhibitor, effectively ameliorates ASD/OVAinduced asthmatic lung inflammation via the inhibition of Th2-mediated IL-13 production. Thus, this study suggests the potential of PDE7 as a therapeutic target for asthmatic lung inflammation.

Acknowledgements This research was supported by the Basic Science Research Program through the National Research Foundation of Korea (NRF), funded by the Ministry of Education (Grant Number NRF-2018R1C1B6008326), and by the Chung-Ang University Research Scholarship Grants in 2020.

\section{Declarations}

Conflict of interest The authors declare that there are no conflicts of interest.

\section{References}

Al-Sajee D, Yin X, Gauvreau GM (2019) An evaluation of roflumilast and PDE4 inhibitors with a focus on the treatment of asthma. Expert Opin Pharmacother 20:609-620. https://doi.org/10.1080/ 14656566.2019.1570132

Alevy YG, Patel AC, Romero AG, Patel DA, Tucker J, Roswit WT, Miller CA, Heier RF, Byers DE, Brett TJ, Holtzman MJ (2012) IL-13-induced airway mucus production is attenuated by MAPK13 inhibition. J Clin Invest 122:4555-4568. https://doi.org/ 10.1172/jci64896

Bonser LR, Erle DJ (2017) Airway mucus and asthma: the role of MUC5AC and MUC5B. J Clin Med 6:112. https://doi.org/10. 3390/jcm6120112
Borger P, Kauffman HF, Postma DS, Vellenga E (1996) Interleukin-4 gene expression in activated human $t$ lymphocytes is regulated by the cyclic adenosine monophosphate-dependent signaling pathway. Blood 87:691-698. https://doi.org/10.1182/blood.V87.2.691. bloodjournal872691

Chen Y, He S-D, Li X-D, Hu Z-L, Zhang C, Xu F (2020a) Long noncoding RNA atlas of the inflammation caused by asthma in mice. Arch Pharmacal Res 43:421-432. https://doi.org/10.1007/ s12272-020-01223-4

Chen Y, Li S, Zhong X, Kang Z, Chen R (2020b) PDE-7 inhibitor BRL-50481 reduces neurodegeneration and long-term memory deficits in mice following sevoflurane exposure. ACS Chem Neurosci 11:1353-1358. https://doi.org/10.1021/acschemneu ro.0c00106

Curtis JL, Warnock ML, Arraj SM, Kaltreider HB (1990) Histologic analysis of an immune response in the lung parenchyma of mice. Angiopathy accompanies inflammatory cell influx. Am J Pathol 137:689-699

Fanta CH (2009) Asthma. N Engl J Med 360:1002-1014. https://doi. org/10.1056/NEJMra0804579

Fortin M, D'anjou H, Higgins ME, Gougeon J, Aube P, Moktefi K, Mouissi S, Seguin S, Seguin R, Renzi PM, Paquet L, Ferrari N (2009) A multi-target antisense approach against PDE4 and PDE7 reduces smoke-induced lung inflammation in mice. Respir Res 10:39. https://doi.org/10.1186/1465-9921-10-39

Grader-Beck T, Van Puijenbroek AFL, Nadler LM, Boussiotis VA (2003) cAMP inhibits both Ras and Rap1 activation in primary human T lymphocytes, but only Ras inhibition correlates with blockade of cell cycle progression. Blood 101:998-1006. https://doi.org/10.1182/blood-2002-06-1665

Ha HS, Lee SE, Lee HS, Kim GH, Yoon CJ, Han JS, Lee J-Y, Sohn UD (2017) The signaling of protease-activated receptor-2 activating peptide-induced contraction in cat esophageal smooth muscle cells. Arch Pharmacal Res 40:1443-1454. https://doi. org/10.1007/s12272-017-0975-1

He M, Ichinose T, Yoshida S, Yamamoto S, Inoue K, Takano H, Yanagisawa R, Nishikawa M, Mori I, Sun G, Shibamoto T (2012) Asian sand dust enhances murine lung inflammation caused by Klebsiella pneumoniae. Toxicol Appl Pharmacol 258:237-247. https://doi.org/10.1016/j.taap.2011.11.003

Honda A, Matsuda Y, Murayama R, Tsuji K, Nishikawa M, Koike E, Yoshida S, Ichinose T, Takano H (2014) Effects of Asian sand dust particles on the respiratory and immune system. J Appl Toxicol 34:250-257. https://doi.org/10.1002/jat.2871

Honda A, Sawahara T, Hayashi T, Tsuji K, Fukushima W, Oishi M, Kitamura G, Kudo H, Ito S, Yoshida S, Ichinose T, Ueda K, Takano H (2017) Biological factor related to Asian sand dust particles contributes to the exacerbation of asthma. J Appl Toxicol 37:583-590. https://doi.org/10.1002/jat.3395

Ichinose T, Sadakane K, Takano H, Yanagisawa R, Nishikawa M, Mori I, Kawazato H, Yasuda A, Hiyoshi K, Shibamoto T (2006) Enhancement of mite allergen-induced eosinophil infiltration in the murine airway and local cytokine/chemokine expression by Asian sand dust. J Toxicol Environ Health Part A 69:15711585. https://doi.org/10.1080/15287390500470833

Ingram JL, Kraft M (2012) IL-13 in asthma and allergic disease: asthma phenotypes and targeted therapies. J Allergy Clin Immunol 130:829-842. https://doi.org/10.1016/j.jaci.2012.06.034

Jin SL, Goya S, Nakae S, Wang D, Bruss M, Hou C, Umetsu D, Conti M (2010) Phosphodiesterase 4B is essential for T(H)2-cell function and development of airway hyperresponsiveness in allergic asthma. J Allergy Clin Immunol 126:1252-1259. https://doi. org/10.1016/j.jaci.2010.08.014

Kang IG, Jung JH, Kim ST (2012) Asian sand dust enhances allergen-induced th2 allergic inflammatory changes and mucin 
production in BALB/c mouse lungs. Allergy Asthma Immunol Res 4:206-213. https://doi.org/10.4168/aair.2012.4.4.206

Kim WD (1997) Lung mucus: a clinician's view. Eur Respir J 10:1914-1917. https://doi.org/10.1183/09031936.97.10081914

Kim S-G, Lee E, Park N-Y, Park H-H, Jeong K-T, Kim K-J, Lee YJ, Jin M, Lee E (2016) Britanin attenuates ovalbumin-induced airway inflammation in a murine asthma model. Arch Pharmacal Res 39:1006-1012. https://doi.org/10.1007/s12272-016-0783-z

Lee C-D, Lee J-K, Jeong JH, Park ES, Dong SU, Hyuk LJ, Wook SJ, Lee J-Y (2018) Inhibitory effects of an extract mixture of ivy (Hedera helix) leaves and Coptidis rhizoma on ovalbumininduced allergic lung inflammation by co-exposure to Asian sand dust in mice. Yakhak Hoeji 62:21-29. https://doi.org/10. 17480/psk.2018.62.1.21

Lee CD, Choi WS, Choi YG, Kang HS, Lee WT, Kim HJ, Lee JY (2020) Inhibition of phosphodiesterase suppresses allergic lung inflammation by regulating MCP-1 in an OVA-induced asthma murine model with co-exposure to lipopolysaccharide. J Int Med Res 48:300060520903663. https://doi.org/10.1177/0300060520 903663

Lugnier C, Al-Kuraishy HM, Rousseau E (2021) PDE4 inhibition as a therapeutic strategy for improvement of pulmonary dysfunctions in Covid-19 and cigarette smoking. Biochem Pharmacol 185:114431. https://doi.org/10.1016/j.bcp.2021.114431

Martínez-Rivera C, Crespo A, Pinedo-Sierra C, García-Rivero JL, Pallarés-Sanmartín A, Marina-Malanda N, Pascual-Erquicia S, Padilla A, Mayoralas-Alises S, Plaza V, López-Viña A, Picado C (2018) Mucus hypersecretion in asthma is associated with rhinosinusitis, polyps and exacerbations. Respir Med 135:22-28. https:// doi.org/10.1016/j.rmed.2017.12.013

Matera MG, Page C, Cazzola M (2014) PDE inhibitors currently in early clinical trials for the treatment of asthma. Expert Opin Investig Drugs 23:1267-1275. https://doi.org/10.1517/13543784.2014. 921157

Maurice DH, Ke H, Ahmad F, Wang Y, Chung J, Manganiello VC (2014) Advances in targeting cyclic nucleotide phosphodiesterases. Nat Rev Drug Discov 13:290-314. https://doi.org/10.1038/ $\operatorname{nrd} 4228$

Mokry J, Joskova M, Mokra D, Christensen I, Nosalova G (2013) Effects of selective inhibition of PDE4 and PDE7 on airway reactivity and cough in healthy and ovalbumin-sensitized guinea pigs. Adv Exp Med Biol 756:57-64. https://doi.org/10.1007/ 978-94-007-4549-0_8

Page CP (2014) Phosphodiesterase inhibitors for the treatment of asthma and chronic obstructive pulmonary disease. Int Arch Allergy Immunol 165:152-164. https://doi.org/10.1159/000368800

Rucilova V, Swierczek A, Vanda D, Funk P, Lemrova B, Gawalska A, Bucki A, Nowak B, Zadrozna M, Pociecha K, Soural M, Wyska E, Pawlowski M, Chlon-Rzepa G, Zajdel P (2020) New imidazopyridines with phosphodiesterase 4 and 7 inhibitory activity and their efficacy in animal models of inflammatory and autoimmune diseases. Eur J Med Chem 209:112854. https://doi.org/10.1016/j. ejmech.2020.112854

Seibold MA (2018) Interleukin-13 stimulation reveals the cellular and functional plasticity of the airway epithelium. Ann Am Thorac Soc 15:S98-S102. https://doi.org/10.1513/AnnalsATS. 201711-868MG

Sethi GS, Sharma S, Naura AS (2019) PARP inhibition by olaparib alleviates chronic asthma-associated remodeling features via modulating inflammasome signaling in mice. IUBMB Life 71:1003-1013. https://doi.org/10.1002/iub.2048

Shin JM, Kim HJ, Park JH, Hwang YJ, Lee HM (2019) Asian sand dust regulates IL-32 production in airway epithelial cells: inhibitory effect of glucocorticoids. Am J Rhinol Allergy 33:403-412. https://doi.org/10.1177/1945892419839538

Smith SJ, Cieslinski LB, Newton R, Donnelly LE, Fenwick PS, Nicholson AG, Barnes PJ, Barnette MS, Giembycz MA (2004) Discovery of BRL 50481 [3-( $N, N$-dimethylsulfonamido)-4-methyl-nitrobenzene], a selective inhibitor of phosphodiesterase 7: in vitro studies in human monocytes, lung macrophages, and CD8+ T-lymphocytes. Mol Pharmacol 66:1679-1689. https://doi. org/10.1124/mol.104.002246

Takeshita S, Tokunaga T, Tanabe Y, Arinami T, Ichinose T, Noguchi E (2015) Asian sand dust aggregate causes atopic dermatitis-like symptoms in Nc/Nga mice. Allerg Asthma Clin Immunol 11:3. https://doi.org/10.1186/s13223-015-0068-y

Torphy TJ (1998) Phosphodiesterase isozymes: molecular targets for novel antiasthma agents. Am J Respir Crit Care Med 157:351370. https://doi.org/10.1164/ajrccm.157.2.9708012

Tukler Henriksson J, Coursey TG, Corry DB, De Paiva CS, Pflugfelder SC (2015) IL-13 stimulates proliferation and expression of mucin and immunomodulatory genes in cultured conjunctival goblet cells. Investig Ophthalmol Vis Sci 56:4186-4197. https:// doi.org/10.1167/iovs.14-15496

Watanabe M, Noma H, Kurai J, Sano H, Mikami M, Yamamoto H, Ueda Y, Touge H, Fujii Y, Ikeda T, Tokuyasu H, Konishi T, Yamasaki A, Igishi T, Shimizu E (2016) Effect of Asian dust on pulmonary function in adult asthma patients in western Japan: a panel study. Allergol Int 65:147-152. https://doi.org/10.1016/j. alit.2015.10.002

Yeon S-M, Choi A, Hong MS, Jung YW (2019) Mediators of the homeostasis and effector functions of memory Th2 cells as novel drug targets in intractable chronic allergic diseases. Arch Pharmacal Res 42:754-765. https://doi.org/10.1007/s12272-019-01159-4

Yim J, Lim HH, Kwon Y (2021) COVID-19 and pulmonary fibrosis: therapeutics in clinical trials, repurposing, and potential development. Arch Pharmacal Res 44:499-513. https://doi.org/10.1007/ s12272-021-01331-9

Zhao J, Maskrey B, Balzar S, Chibana K, Mustovich A, Hu H, Trudeau JB, O'donnell V, Wenzel SE (2009) Interleukin-13-induced MUC5AC is regulated by 15-lipoxygenase 1 pathway in human bronchial epithelial cells. Am J Respir Crit Care Med 179:782790. https://doi.org/10.1164/rccm.200811-1744OC

Zhu Z, Homer RJ, Wang Z, Chen Q, Geba GP, Wang J, Zhang Y, Elias JA (1999) Pulmonary expression of interleukin-13 causes inflammation, mucus hypersecretion, subepithelial fibrosis, physiologic abnormalities, and eotaxin production. J Clin Invest 103:779-788. https://doi.org/10.1172/JCI5909

Zurawski G, De Vries JE (1994) Interleukin 13, an interleukin 4-like cytokine that acts on monocytes and B cells, but not on T cells. Immunol Today 15:19-26. https://doi.org/10.1016/0167-5699(94) 90021-3

Publisher's Note Springer Nature remains neutral with regard to jurisdictional claims in published maps and institutional affiliations. 